\title{
INVENTARISASI TUMBUHAN OBAT TRADISIONAL DI KECAMATAN WERA KABUPATEN BIMA
}

\author{
Nikman Azmin ${ }^{1}$, Anita Rahmawati ${ }^{2}$, Kartini $^{3}$ \\ 123Program Studi Pendidikan Biologi, STKIP Bima \\ Email: biologinikman@gmail.com
}

\begin{abstract}
Abstrak
Penggunaan dan pemanfaatan potensi tumbuhan obat tradisional menunjukkan peningkatan, hal ini terbukti dari penggunaan bahan alam di berbagai negara maju mencapai 65\% sementara itu diperkirakan ada 9.600 spesies tumbuhan yang telah dimanfaatkan oleh 400 ragam suku yang ada di Indonesia. Pada umumnya masyarakat Kecematan Wera mengetahui khasiat tumbuhan obat tradisional berdasarkan kepercayaan yang mengakar kuat yang diwariskan secara turun temurun. Penelitian bertujuan untuk mengetahui jenis jenis tumbuhan obat dan bagian yang di manfaatkan serta khashiat tumbuhan. Metode penelitian yang digunakan yaitu kombinasi teknik survei lapangan (observasi), teknik wawancara secara mendalam (in depth interview), dan teknik kuesioner. Analisis data menggunakan analisis deksriptif kualitatif dan kuantitatif. Hasil penelitian menunjukan bahwa tumbuhan obat tradisional yang dimanfaatkan sebagai obat sebanyak 27 jenis tumbuhan berkhasiat obat yang digunakan dalam pengobatan tradisional
\end{abstract}

\section{Kata kunci : Inventarisasi, Tumbuhan Obat Tradisional, Kecamatan Wera}

\section{PENDAHULUAN}

Indonesia merupakan salah satu negara kepulauan terbesar di dunia yang memiliki keanekaragaman tumbuhan yang tinggi, dari sekian banyak keanekaragaman tumbuhan, terdapat tumbuhan yang berkhasiat sebagai obat-obatan dan telah digunakan sebagai pengobatan tradisional berdasarkan pada pengalaman dan keterampilan secara turun temurun yang masih dimanfaatkan hingga saat ini. Obat-obat tradisional umumnya menggunakan bahan-bahan alamiah seperti akar, batang, daun, bunga dan buah (Nugroho, 2010).

Perhatian terhadap obat-obatan tradisional menunjukkan peningkatan, hal ini terbukti dari penggunaan obat bahan alam di negara maju mencapai $65 \%$ sementara itu diperkirakan ada 9.600 spesies tumbuhan yang telah dimanfaatkan oleh 400 ragam etnis atau suku yang ada di indonesia (Agustina dkk, 2016). Tumbuhan obat merupakan salah satu sumber kekayaan alam yang potensial, namun belum banyak dimanfaatkan (Martiningsih, 2018). Pada umumnya masyarakat mengetahui khasiat obat tradisional berdasarkan kepercayaan yang mengakar kuat dalam masyarakat kita secara turun temurun, seperti halnya pada masyarakat Bima, khusus nya Kecamatan Wera Kabupaten Bima (Azmin dkk, 2019). 
Kecamatan Wera merupakan suatu wilayah yang terletak di Kabupaten Bima Propinsi Nusa Tenggara Barat (NTB) yang terletak pada ketinggian $3000 \mathrm{~m}$ dpl dan berbentuk dataran tinggi. Letak geografis yang sulit di jangkau serta tempat dengan dataran tinggi, jauh dari rumah sakit menyebabkan masyarakat Wera lebih menggunakan obat tradisional yang sudah di yakini sebagai obat. Pengetahuan tentang pemanfaatan tumbuhan obat secara tradisional di Kecamatan Wera selama ini belum diteliti dan dikaji secara mendalam sehingga belum ada data dan informasi yang menyatakan jenis-jenis tumbuhan obat serta pemanfaatan yang digunakan oleh masyarakat. Pengetahuan tentang penggunaan dan pemanfaatan tumbuhan obat ini hanya diwariskan secara lisan sehingga tidak menutup kemungkinan bahwa lama kelamaan hal ini akan menghilang atau resepnya tidak komplit. Berdasarkan hal tersebut perlu dilakukan penelitian tentang inventarisasi jenis-jenis tumbuhan serta pengolahan yang dimanfaatkan sebagai obat tradisonal oleh masyarakat yang berada di Kecamatan Wera.

\section{METODE}

\section{Alat dan Bahan}

Alat yang digunakan antara lain rol meter, GPS, kamera, kuesioner, koran, plastik clip ukuran $150 \mathrm{~cm}$ x $100 \mathrm{~cm}$, spidol permanen, alat tulis menulis, dan perlengkapan kemah. Bahan yang digunakan dalam penelitian ini adalah peta kawasan Daerah Bima, alkohol, aquadest, sampel bagian tumbuhan yang dimanfaatkan sebagai obat tradisional.

\section{Prosedur Penelitian}

Pengumpulan data yang digunakan yaitu kombinasi teknik survei lapangan (observasi), teknik wawancara secara mendalam (in depth interview), dan teknik kuesioner. Informan ditentukan berdasarkan keterangan dari tokoh masyarakat adat, kepala suku, kepala desa, kepala kampung, dan sumber terpercaya lainnya yang mengetahui hal-hal yang berkaitan erat dengan kegiatan yang akan dilaksanakan. Responden sebanyak 15 orang.

\section{Rancangan Penelitian}

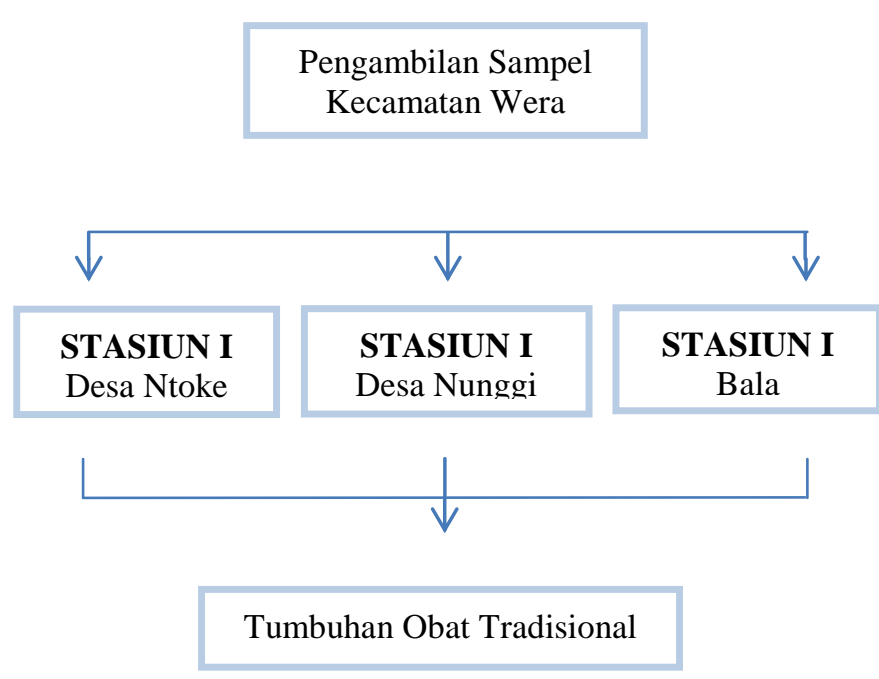

Gambar 1. Rancangan Penelitian 


\section{HASIL DAN PEMBAHASAN}

Topografi Wilayah Kecematan Wera Kabupaten Bima pada umumnya mempunyai wilayah topografi yang bervariasi berupa perbukitan, pegunungan, lembah dan sungai dengan ketinggian 250-3000 meter dpl serta sebagai wilayah pedalaman mempunyai wilayah pantai. Secara umum keadaan Topografi Wilayah wilayah didominasi oleh bukit-bukit dan gunung-gunung yaitu sekitar 90\% dari luas wilayah Kecematan Wera, sedangkan yang datar hanya 10\% (Azmin dkk, 2019).

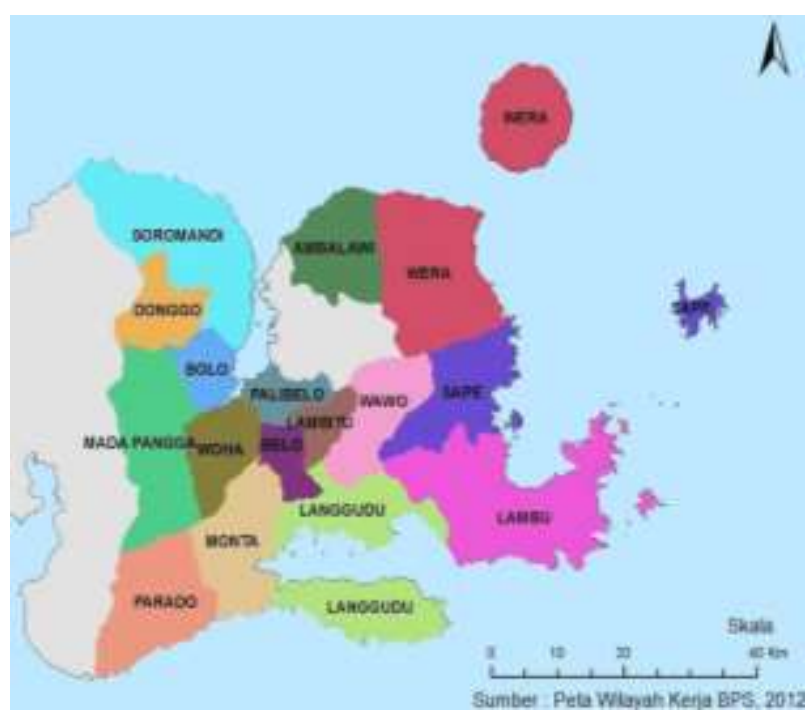

Gambar 2. Peta Kecamatan Wera

\section{Potensi Tumbuhan Obat di Kecamatan Wera Kabupaten Bima}

Berdasarkan data hasil observasi dan wawancara di beberapa desa menunjukan bahwa masyarakat Kecematan Wera yang tinggal dan bermukim disekitar huta dan pegunungan pada umumnya telah mengetahui dan memanfaatkan berbagai jenis tumbuhan obat tradisonal untuk kebutuhan kehidupan sehari-hari mereka ada juga masyarakat Wera yang mengunakan tumbuhan obat tradisional untuk di perjual belikan dalam bentuk jamu atau dalam bahasa Daerah Masyarakat Bima (lo'i pa'i) untuk membantu peningkatan penghasilan masyarakat. Salah satu pemanfaatan yang hingga kini masih dapat ditemukan dan terus dilestarikan khususnya pada wilayah Kecematan Wera yaitu penggunaan tumbuhan sebagai ramuan obat tradisional. Adapun Jenis penyakit yang diobati cukup beragam dan bervariasi mulai penyakit alergi, luka ringan pada kulit, penyakit dalam kronis hingga penyakit akibat kekuatan supernatural (Kekuatan gaib), hal ini diyakini oleh masyarakat setempat sebagai tradisi yang bermanfaat untuk pengobatan. Karakteristik tumbuhan obat dan cara pemanfaatannya pun memiliki ciri khas pada masing-masing lokasi penelitian, sesuai pengetahuan dan pengalaman yang dimiliki serta serta diwariskan secara turun temurun (Nurrani dan Tabba, 2015).

Berdasarkan analisis data hasil wawancara yang berasal dari Responden di masing-masing Desa yang ada di Kecematan Wera diperoleh informasi tentan jenis-jeis tumbuhan obat tradisional yang digunakan dan di manfaatkan sebagai obat dalam pengobatan berbagai penyakit. Hal ini dapat dilihat pada tabel berikut ini: 
Tabel 1. Jenis-Jenis Tumbuhan yang Digunakan Setiap Obat, sebagaimana tabel dibawah ini

\begin{tabular}{|c|c|c|c|c|c|}
\hline $\begin{array}{l}\text { Nama } \\
\text { Tumbuhan }\end{array}$ & $\begin{array}{l}\text { Nama } \\
\text { Ilmiah }\end{array}$ & $\begin{array}{l}\text { Nama } \\
\text { Daerah }\end{array}$ & $\begin{array}{c}\text { Bagian yang } \\
\text { Digunakan }\end{array}$ & Kegunaannya & Cara Meramunya \\
\hline Belimbing & Averrhoa carambola & Limbi & Daun & $\begin{array}{c}\text { Mengobati } \\
\text { penyakit maag }\end{array}$ & $\begin{array}{l}\text { Siapkan lebih kurang } 10 \text { helai daun belimbing, } \\
\text { seujung jari kunyit, seujung jari temu kunci } \\
\text { dan setengah gelas air. Rebus semua bahan } \\
\text { dengan api sedang, saring dan minum satu } 1 x \\
\text { sehari. }\end{array}$ \\
\hline Jarak & Jatropha curcas L & Tatanga & Daun & Sakit perut & $\begin{array}{l}\text { Pilih daun jarak yang dengan permukaan yang } \\
\text { lebar, oleleskan minyak kelapa terlebih } \\
\text { dahulu lalu tempelkan pada perut dan tunggu } \\
\text { hasilnya. }\end{array}$ \\
\hline Pacar kuku & $\begin{array}{c}\text { Lawsonia inermis } \\
\text { L. }\end{array}$ & Kapanca & Daun & Bengkak & $\begin{array}{l}\text { Ambil segenggam daun pacar kuku, lalu } \\
\text { tumbuk hingga halus, , dan tempelkan } \\
\text { kebagian yang bengkak. }\end{array}$ \\
\hline Jambu klutuk & Psidium guajava $L$. & Jambu doro & Daun & Mengobati diare & $\begin{array}{l}\text { Daun mudanya dimakan secara langsung tanpa } \\
\text { diolah }\end{array}$ \\
\hline Jeruk nipis & $\begin{array}{c}\text { Citrus } x \\
\text { aurantiifolia }\end{array}$ & Gungga ncia & Buah & $\begin{array}{l}\text { Mengobati } \\
\text { batuk }\end{array}$ & $\begin{array}{l}\text { Buah jeruk di peras lalu } \\
\text { diminum }\end{array}$ \\
\hline Katuk & $\begin{array}{c}\text { Sauropus } \\
\text { androgynous }(L) .\end{array}$ & Ro’o kambesi & Daun & $\begin{array}{l}\text { Pelancar ASI, } \\
\text { panas dalam } \\
\text { pada anak }\end{array}$ & $\begin{array}{l}\text { Memperlancar ASI: Olah daun katuk menjadi } \\
\text { sayur dan di konsumsi untuk memperlancar } \\
\text { asi dan Panas dalam pada anak: siapkan } \\
\text { beberapa helai daun katuk, kemudian tumbuk } \\
\text { halus tambahkan sedikit air matang kemudian } \\
\text { peras ambil airnya.campurkan sedikit gula lalu } \\
\text { minumkan. }\end{array}$ \\
\hline Katuk & $\begin{array}{l}\text { Sauropus } \\
\text { androgynous }(L) .\end{array}$ & Ro'o kambesi & Daun & $\begin{array}{l}\text { Memperlancar } \\
\text { ASI }\end{array}$ & Daun katuk direbus dan dikonsumsi \\
\hline Kencur & $\begin{array}{l}\text { Kaempferia } \\
\text { galapanga } L .\end{array}$ & Souk & Rimpang & $\begin{array}{l}\text { Mengobati } \\
\text { batuk }\end{array}$ & Dimakan secara langsung / dilalap \\
\hline Kelapa & Cocos nucifera $L$. & Ni’u & Buah & $\begin{array}{l}\text { Mingobati } \\
\text { panas dalam }\end{array}$ & $\begin{array}{l}\text { Air dari kelapa diminum secara langsung / } \\
\text { tanpa diramu }\end{array}$ \\
\hline Kemangi & $\begin{array}{l}\text { Ocimum } \\
\text { xcitriodorum }\end{array}$ & Pa taha & Daun & $\begin{array}{l}\text { Menghilangkan } \\
\text { bau badan }\end{array}$ & $\begin{array}{l}\text { Kemanginya di makan secara langsung/ di } \\
\text { lalap }\end{array}$ \\
\hline Kersen & $\begin{array}{l}\text { Muntingia calabura } \\
\text { L. }\end{array}$ & Anggo & Daun & $\begin{array}{l}\text { Mengobati } \\
\text { darah tinggi }\end{array}$ & $\begin{array}{l}\text { Daun kersen dikeringkan, setelah kering } \\
\text { diseduh dengan air panas seperti teh diminum } \\
1-2 \text { kali sehari }\end{array}$ \\
\hline Krokot & $\begin{array}{l}\text { Portaluca leavis } \\
\text { wall }\end{array}$ & Soka & $\begin{array}{l}\text { Seluruh bagian } \\
\text { tumbuhan }\end{array}$ & Mengobati wasir & $\begin{array}{l}\text { Krokot segar kurang lebih sebanyak } 120 \text { gram } \\
\text { dilumatkan ,diperas airnya kemudian airnya } \\
\text { diminum. }\end{array}$ \\
\hline Kumis kucing & $\begin{array}{l}\text { Orthosiphoon } \\
\text { staineus benth }\end{array}$ & $\begin{array}{l}\text { Kumis } \\
\text { kucing }\end{array}$ & Daun dan akar & $\begin{array}{l}\text { Mengobati sakit } \\
\text { pinggang }\end{array}$ & $\begin{array}{l}\text { Cucilah daun dan akar kumis kucing hingga } \\
\text { bersih, masukan keduanya yang berisi segelas } \\
\text { air, lalu rebus hingga mendidih, angkat dan } \\
\text { biarkan dingin semalaman. Paginya barua } \\
\text { dapat diminum, lakukan secara rutin. }\end{array}$ \\
\hline Kunyit & $\begin{array}{l}\text { Curcuma domestica } \\
\text { Val. }\end{array}$ & Huni & Rimpang & $\begin{array}{l}\text { Mengobati sakin } \\
\text { maag }\end{array}$ & $\begin{array}{l}\text { Sediakan kunyit sekitar } 3 \text { ruas berikut dengan } \\
\text { air sesuai kebutuhan , kupas dan potong- } \\
\text { potong - rebuslah sampai mendidih dan } \\
\text { tunggu hingga airnya sampai menguap baru di } \\
\text { angkat. saring lah sebelum dikonsumsi. }\end{array}$ \\
\hline Lempuyang & $\begin{array}{l}\text { Zingiber } \\
\text { aromaticum }\end{array}$ & Kampuja & Rimpang & $\begin{array}{l}\text { Meningkatkan } \\
\text { napsu makan }\end{array}$ & $\begin{array}{l}\text { Rimpang lempuyang dicuci hingga bersih, } \\
\text { kemudian parut hingga halus . diperas lalu } \\
\text { disaring, untuk menghilangkan rasa pahit } \\
\text { tambahkan gula, lalu diminum. }\end{array}$ \\
\hline Lengkuas & $\begin{array}{l}\text { Alpinia } \text { galangal } \\
(L) .\end{array}$ & Lau & Rimpang & $\begin{array}{l}\text { Menyembuhkan } \\
\text { gangguan perut / } \\
\text { kembung }\end{array}$ & $\begin{array}{l}\text { Lengkuas liris tipis, rebus dengan } 3 \text { gelas air } \\
\text { menjadi } 2 \text { gelas, minum pagi dan sore sebelum } \\
\text { makan. }\end{array}$ \\
\hline Lidah buaya & Aloe vera $L$. & Lidah buaya & Lendir & $\begin{array}{l}\text { Menyuburkan } \\
\text { rambut }\end{array}$ & $\begin{array}{l}\text { Lidah buaya di potong dan getahnya di } \\
\text { gosokkan ke rambut, biarkan beberapa saat } \\
\text { lalu bilas }\end{array}$ \\
\hline Mengkudu & Mirinda citrifola & Nonu & Buah & $\begin{array}{l}\text { Menurunkan } \\
\text { tekanan darah } \\
\text { tinggi }\end{array}$ & $\begin{array}{l}\text { Ambil lah mengkudu matang lalu diparut } \\
\text { untuk kemudian diperas airnya , tambahkan } \\
\text { madu murni } 1 \text { sensok makan lalu siap untuk } \\
\text { dikonsumsi } 1 \text { kali sehari. }\end{array}$ \\
\hline
\end{tabular}

\section{Sumber Data; Hasil Wawancara}


Berdasarkah tabel 1 diatas menunjukan bahwa hasil kusioner dari 15 responden diketahui bahwa terdapat 27 jenis tumbuhan obat yang umum dimanfaatkan oleh masyarakat kecematan Wera. Umumnya tumbuhan tersebut diambil disekitar hutan dan pegunungan, maupun di kebun masing, namun ada juga masyarakat yang menanam dan membudidayakan jenis tumbuhan obat untuk dimanfaatkan sebagai obat Toga. Adapun pemanfaatan tumbuhan obat tradisional yaitu melalui budidaya seperti perbanyakan pada batang, tunas dan ada pula yang melalui biji. Hal ini dilakukan untuk menjaga populasi tumbuhan obat sehingga terjaga dan terawat untuk diwariskan dari generasi ke generasi. Menurut Miftahul et al, (2016), yang menyatakan bahwa daerah Kecematan Wera Kabupaten Bima adalah daerah yang beriklim tropis yang bersuhu dingin karena terdiri dari pegunungan, dan bukit-bukit yang saling sambung menyambung. Pemanfaatan tumbuhan obat sebagai obat dapat digunakan dengan berbagai campuran tumbuhan obat untuk satu jenis penyakit atau satu tumbuhan untuk beberapa jenis penyakit (Ariefa, 2013).

\section{KESIMPULAN}

1. Hasil inventarisasi tumbuhan obat terdapat 27 jenis tumbuhan obat yang digunakan oleh Masyarakat Kecematan Wera.
2. Tumbuhan obat tradisisonal yang dimanfaatkan oleh di Masyarakat Wera terbilang masih tradisional dalam aspek pembuatan obat baik sebagai jamu maupun sebagai Lo,I Pa,i. cara yang digunakan oleh masyarakat dalam melakukan pengobatan dengan memanfaatkan bahan-bahan yang utamanaya berasal dari tumbuhan obat

\section{DAFTAR PUSTAKA}

Agustina. S., Ruslan dan Agrippina. W. 2016. Skrining Fitokimia Tanaman Obat Di Kabupaten Bima. Cakra Kimia (Indonesian E-Journal of Applied Chemistry) Volume 4, Nomor 1, hal 71-76.

Azmin, N., Rahmawati, A., \& Hartati, H. (2019). Studi Etnobotani Dalam Pemanfaatan Tumbuhan Obat Tradisional Berbasis Pengetahuan Lokal Di Kecematan Madapangga Kabupaten Bima. In Proceeding National Conference: Education, Social Science, and Humaniora (Vol. 1, No. 1, pp. 146-158).

Azmin, N., Rahmawati, A., \& Hidayatullah, M. E. (2019). Uji Kandungan fitokimia dan Etnobotani Tumbuhan Obat Tradisional Berbasis Pengetahuan Lokal di Kecematan Lambitu Kabupaten Bima. Florea: Jurnal Biologi dan Pembelajarannya,6(2), 101-113.

Ariefa, P.Y. 2013. Kearifan Lokal Penggunaan Tumbuhan Obat Oleh Suku Lembak 
Delapan Di Kabupaten Bengkulu

Tengah, Bengkulu. Prosiding Semirata

FMIPA Universitas Lampung.

Azmin, N., \& Rahmawati, A. (2019, February). Kearifan Lokal Dalam Pemanfaatan Tumbuhan Obat

Tradisional Oleh Masyarakat Daerah Bima. In Prosiding Seminar Nasional II APPPI NTB 2018 (Vol. 1, No. 1).

Azmin, N., Nasir, M., \& Hartati, H. (2019). Pemanfaatan Kulit Udang (Penaeus Modonon) Untuk Pembuatan Kitosan Sebagai Pengawet Alami

Daging. Jurnal Oryza: Jurnal Pendidikan Biologi, 8(1), 9-15.

Martiningsih, Nasir M., Azmin N. (2018) Inventarisasi Berbagai Jenis Tumbuhan Obat Tradisional Di Kecamatan Wawo Sebagai Kearifan Lokal Masyarakat Bima. Oryza Jurnal Pendidikan Biologi, Vol. 7, No. 2, Hal: 8-13.

Miftahul, J dan Muhammad Saleh Madjid. 2016. Luas Wilayah Kabupaten Bima (2001-2014). Jurnal Pemikiran Pendidikan Dan Penelitian Kesejarahan, Vol 3, No 